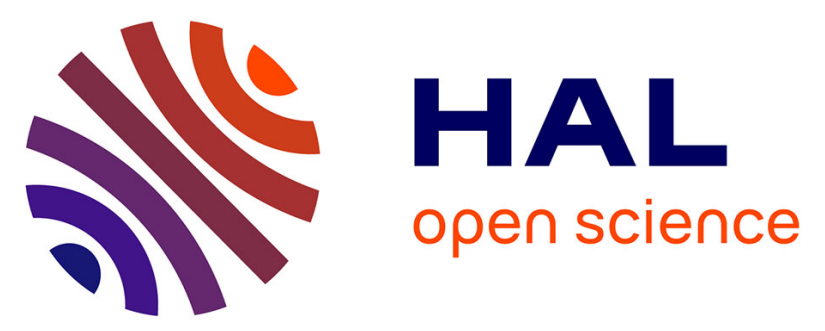

\title{
A non-local damage model for heterogeneous rocks - application to rock fracturing evaluation under gas injection conditions
}

Darius Seyedi, Guy Nicolas, François Hild, Sébastien Meunier, S. Granet

\section{- To cite this version:}

Darius Seyedi, Guy Nicolas, François Hild, Sébastien Meunier, S. Granet. A non-local damage model for heterogeneous rocks - application to rock fracturing evaluation under gas injection conditions. ALERT Geomaterials Workshop, Geomechanical issues in CO2 storage, Oct 2011, Aussois, France. hal-00613173

\section{HAL Id: hal-00613173 https://hal-brgm.archives-ouvertes.fr/hal-00613173}

Submitted on 3 Aug 2011

HAL is a multi-disciplinary open access archive for the deposit and dissemination of scientific research documents, whether they are published or not. The documents may come from teaching and research institutions in France or abroad, or from public or private research centers.
L'archive ouverte pluridisciplinaire HAL, est destinée au dépôt et à la diffusion de documents scientifiques de niveau recherche, publiés ou non, émanant des établissements d'enseignement et de recherche français ou étrangers, des laboratoires publics ou privés. 


\section{A non-local damage model for heterogeneous rocks - application to rock fracturing evaluation under gas injection conditions}

For main author:

For other authors:
Seyedi Darius, BRGM

3 avenue Claude Guillemin, 45060, Orléans, France - d.seyedi@brgm.fr

Guy Nicolas, BRGM, Orléans \& LMT-Cachan, France (now at IFPEN)

Hild François, LMT-Cachan, Cachan, France

Meunier Sébastien, EDF R\&D, Clamart, France

Granet Sylvie, EDF R\&D, Clamart, France

Keywords: Initiation, Non-local damage model, Propagation, Probabilistic approach, hydromechanical coupling

\section{Abstract:}

All underground engineering works have to deal with heterogeneous rock mass (e.g., nuclear waste disposal in geological media, deep underground injection, geothermal energy extraction, enhanced recovery from oil and gas reservoirs, and underground storage of natural gas). More recently, geological storage of carbon dioxide $\left(\mathrm{CO}_{2}\right)$ into permeable deep aquifers has been suggested as an important potential method to reduce the emission of greenhouse gases into the atmosphere. Deep well injection changes the stress state in the geological formation. A change in the stress field may affect the hydraulic response of the medium. The main goal of the present work is to introduce a coupled hydromechanical damage model that takes into account the effect of mechanical heterogeneities on the hydromechanical response of rock masses.

A probabilistic damage model is developed to study possible cracking of the rock due the effective stress changes. Two different thresholds are considered for crack initiation and propagation. A Weibull model is used to account for the stochastic nature of crack initiation(s) and then a fracture mechanics based threshold is considered to model crack propagation. The model is integrated in the finite element package (Code_Aster) as a non-local damage model. Both damage thresholds are checked using a "regularised" stress field to avoid mesh dependence and localization phenomena. The use of the regularized stress enables us to calculate correctly the stress intensity factors for the propagating cracks modelled as a set of completely damaged elements. The interaction between propagating cracks and initiation sites is accounted for naturally through the stress relaxation induced around the existing cracks.

A robust and efficient sequential approach is proposed for hydromechanical coupling. The coupled phenomena of fluid flow in complex geological systems are solved with a thermo-hydraulic module, and the mechanical response of the geological medium is evaluated with the mechanical module of Code_Aster $\AA^{\circledR}$. These processes are linked using a sequential algorithm. The use of a damage variable to represent the induced cracks permits a straightforward damage-permeability relationship to be considered.

Following the above methodology, a typical gas injection example is considered. The effects in terms of effective stress changes for different injection scenarios are assessed. The effect of different in situ parameters such as material heterogeneity, mechanical parameters and initial stress field is studied through parametric analyses and the damage risk is evaluated. 
Figures

............... 